\title{
Technical and environmental characterization of dual-purpose cattle farms and ways of improving production: $A$ case study in Colombia
}

Ricardo González-Quintero ${ }^{1,2^{*}}$ (D), Rolando Barahona-Rosales ${ }^{3}$, Diana María Bolívar-Vergara ${ }^{3}$, Ngonidzashe Chirinda ${ }^{4}$, Jacobo Arango ${ }^{1}$, Heiber Alexander Pantévez ${ }^{5}$, Guillermo Correa-Londoño ${ }^{3}$ and María Solange Sánchez-Pinzón ${ }^{6}$

\begin{abstract}
There are few reports on dual-purpose cattle systems characterization in Latin America and Colombia based on large datasets. This limits our understanding of their dynamics, and the establishment of public policies and government programs to improve their productive performance, promotion and rural development. This study aimed to characterize very small, small, medium, and large dual-purpose farms in Colombia from technical and environmental perspectives. The data analysed were obtained from the Ganadería Colombiana Sostenible and the LivestockPlus projects, which gathered information from a total of 1313 dual-purpose farms in Colombia. Farms were classified as being either very small (1 to 30 bovines), small (31 to 50 bovines), medium (51 to 250 bovines), or large farms (more than 251 bovines). Numerical and categorical variables were distributed into five components: (1) General Farm Information, (2) Herd Composition and Management, (3) Pasture Management, (4) Production Information, and (5) Environmental Information. Each component was analysed using the factorial analysis of mixed data (FAMD) method. According to FAMD, for the components General Farm Information, Herd Composition and Management, Pasture Management, and Production Information, the distribution of variables led to a spatial separation of the centroid from each category of producers. For the component Environmental Information, there was no separation of the centroid. In general, medium-sized and large farms showed better infrastructure, better machinery and equipment, and better reproductive practices; however, this was not reflected in a significant improvement of productive parameters, except for a lower mortality rate. Larger livestock producers need to plan their livestock husbandry activities properly, based on their better available infrastructure and livestock management practices, with the purpose of increasing productivity. The main features identified for each livestock producer category can be the basis to guide and establish policies and programmes for their technological development. The development of better livestock management practices and the implementation of technology, as well as technical assistance, should focus on small- and medium-sized livestock producers, which could lead to reaching a better productive and reproductive performance of dual-purpose systems.
\end{abstract}

Keywords: Activity factors, Colombian livestock sector, Environmental impacts, Factorial analysis of mixed data, Livestock production systems, Public policies

\footnotetext{
* Correspondence: ricardo.gonzalezq@udea.edu.co

'International Center for Tropical Agriculture (CIAT), Km 17 recta Cali, Palmira,

Valle del Cauca, Colombia

${ }^{2}$ Facultad de Ciencias Agrarias, Universidad de Antioquia, Carrera 75 \# 65-87

bloque 47, office 231, Medellin, Colombia

Full list of author information is available at the end of the article
}

\section{Springer Open}

(๑) The Author(s). 2020 Open Access This article is licensed under a Creative Commons Attribution 4.0 International License, which permits use, sharing, adaptation, distribution and reproduction in any medium or format, as long as you give appropriate credit to the original author(s) and the source, provide a link to the Creative Commons licence, and indicate if changes were made. The images or other third party material in this article are included in the article's Creative Commons licence, unless indicated otherwise in a credit line to the material. If material is not included in the article's Creative Commons licence and your intended use is not permitted by statutory regulation or exceeds the permitted use, you will need to obtain permission directly from the copyright holder. To view a copy of this licence, visit http://creativecommons.org/licenses/by/4.0/. 


\section{Introduction}

Colombia has approximately 27.2 million head of cattle (ICA 2019), and is ranked as the fourth Latin American country in terms of highest livestock population, and milk and beef production (FAO 2013). In Colombia 933, 000 tons of beef and 7,301 million liters of milk are produced annually (Fedegan 2019), which come from 623, 794 registered farms, with $82 \%$ of such having less than 50 animals (ICA 2019). Dual-purpose farming accounts for $35.0 \%$ of the Colombian cattle herd (Fedegan 2019), and is an important contributor to those production figures. These numbers highlight the importance of focusing on small producers for the development and improvements for cattle production systems in the country.

Dual-purpose cattle systems (DPS) are defined as those where milk and meat are produced simultaneously, cows are partially milked, the residual milk is consumed by their calves, feed is mainly based on grazing (Ruiz-Guevara et al. 2008), and their productivity (milk or meat per unit area and/or per animal) is lower compared to systems oriented towards the production of milk or beef exclusively (Cortés-Mora et al. 2012). Whilst intensive systems are more productive, it has been reported that they are not as profitable as well-managed DPS (Yamamoto et al. 2007; Puebla-Albiter et al. 2015). This suggests that DPS may have lower production costs per unit of milk and beef than intensive systems (Holmann et al. 2003; Magaña-Monforte et al. 2006). The characterization of livestock farms makes it possible to become acquainted with the limitations and potentials of the technical, productive, reproductive, and environmental components. The purpose is to develop plans, projects, and/or public policies for technology development and transfer, to ensure actions are focused on using resources efficiently (Díaz-Castillo et al. 2014).

Reports on dual-purpose cattle systems characterization in Latin America and Colombia, based on large datasets, are few. This limits our understanding of their dynamics, and the establishment of public policies to improve their productive performance, promotion and rural development. Consequently, this study was conducted to characterize very small, small, medium, and large dualpurpose farms across 13 cattle-producing departments of Colombia from a technical and environmental perspective. The aim is to identify the main differences amongst groups and the proper strategies to improve their productive and environmental indicators.

\section{Study area}

The 1313 cattle farms studied were located in the tropical lowlands of the following departments in Colombia: Atlántico, Bolívar, Boyacá, Caldas, Cauca, Cesar, La Guajira, Meta, Quindío, Risaralda, Santander, Tolima, and Valle del Cauca, as indicated in Fig. 1. These 13 departments cover an area of $301,363 \mathrm{~km}^{2}$ with a population of 21,711,637 inhabitants. In Colombian tropical lowlands, the maximum altitude is $1200 \mathrm{~m}$, and the average annual temperature ranges from 18 to $38^{\circ} \mathrm{C}$, with $1100 \mathrm{~mm}$ of annual rainfall averages. The livestock in the 1313 cattle farms mainly consists of bovines.

\section{Methods}

\section{Sampled population}

The information used in this study was obtained from the Sustainable Colombian Cattle Ranching (GCS, Spanish initials) and the LivestockPlus $(\mathrm{L}+)$ projects conducted in Colombia. In these studies, over a period of 1 year, quantitative and qualitative data were collected by applying surveys on farms, to determine a baseline scenario before project interventions. Both projects used a semi-structured questionnaire for collecting data from farmers. The components of the collected information were similar between projects, which allowed us to use it for the current study. Quantitative and qualitative information was provided by the farmers according to their knowledge of the farms, and/or their farm records, where available. In the first project (GCS), a survey was conducted on a total of 2011 farms characterized as cow-calf, cattle fattening, dual-purpose, full cycle, or specialized dairy livestock farms according to the farmer responses during the surveys. Regions where farms are located were selected based on environmental attributes, the presence of globally important ecosystems, and proximity to protected areas. Participation in the GCS project was voluntary. The main criteria for including the farms in the project were being a property owned by a Colombian; being classified as small, medium, or large in size according to the farm area and their location; and not having records of legal issues. Livestock farms surveyed were located in the following departments of Colombia (in parenthesis, the number of municipalities surveyed): Atlántico (13), Bolívar (4), Boyacá (12), Caldas (2), Cesar (10), La Guajira (5), Meta (10), Quindío (9), Risaralda (2), Santander (4), Tolima (6), and Valle del Cauca (7) (Fig. 1). The 10-component questionnaire used on each farm included questions on (1) general information, (2) herd composition and management, (3) pasture management practices, (4) livestock production and reproduction data, (5) animal health, (6) environmental information, (7) social information, (8) organizational and relationships with the external environment, (9) income from livestock, and (10) financial information.

The L+ project conducted a survey amongst farms located in the Meta Piedmont (municipalities of Cumaral and Restrepo), Meta high plains (Puerto Gaitán and Puerto López), and Cauca dry valley of Patía (El Bordo and Mercaderes) in Colombia (Fig. 1). Surveys were conducted in 607 livestock farms as follows: Piedmont 


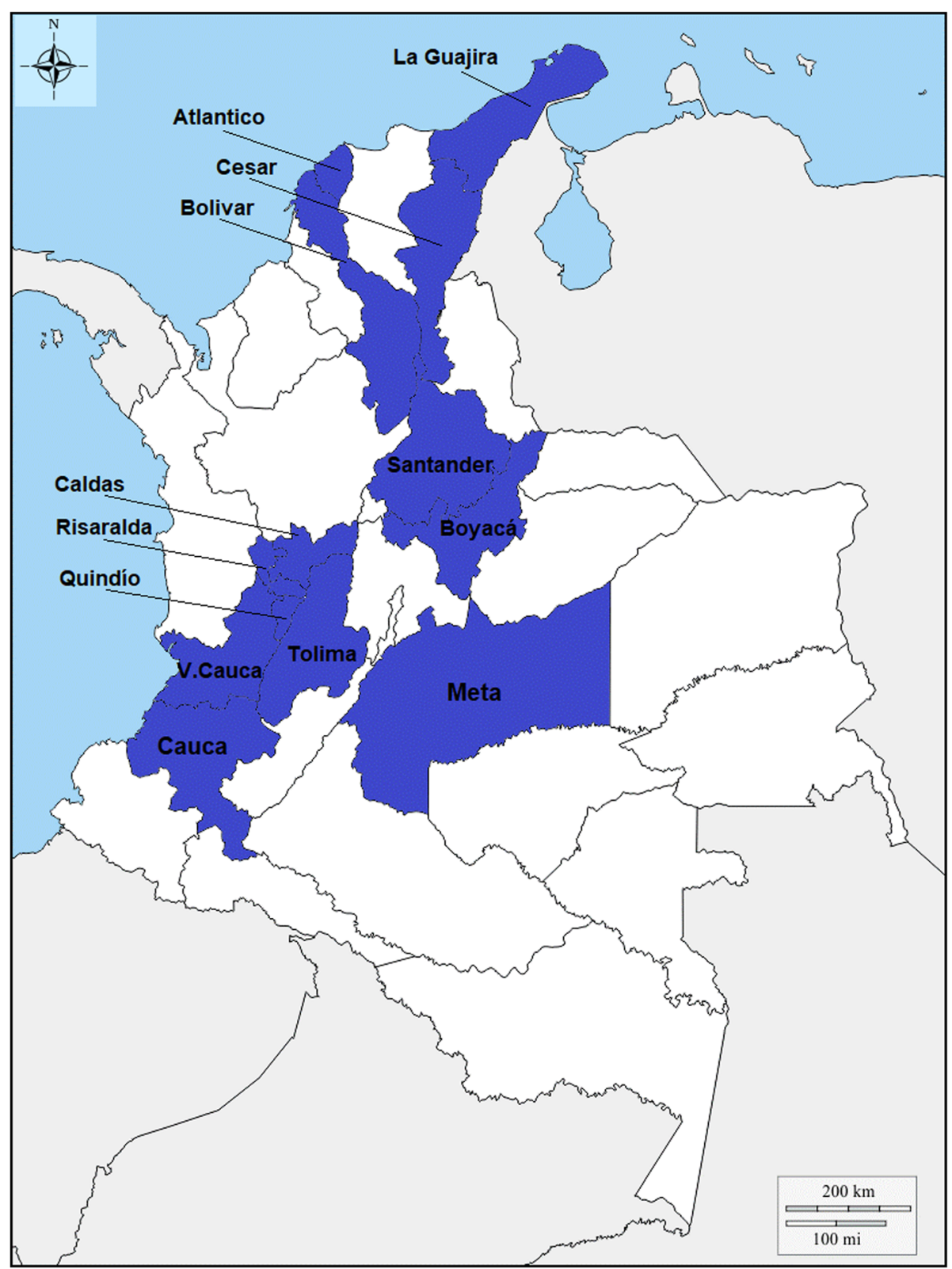

Fig. 1 Departments where surveyed farms were located

(150), High Plains (147), and the dry valley of Patía (310). The questionnaire focused on eight components: (1) general information, (2) administrative information, (3) land-use information, (4) technical assistance, (5) production and trade system characteristics, (6) association membership, (7) financial information, and (8) climate events. Farms were classified as cow-calf, cattle fattening, dual-purpose, full cycle, or specialized dairy livestock farms according to the farmer's statement during the surveys.

From the total combined sample of 2618 livestock farms surveyed, 1313 dual-purpose farms were identified. These were stratified according to their livestock inventories into four categories of producers according to the number of cattle heads (in parenthesis): very small livestock producers (VSP; 1 to 30), small livestock producers (SP; 31 to 50), medium livestock producers (MP: 51 to 250), and large livestock producers (LP; over 251) (Fedegan 2006). Table 1 shows the numeric and categorical variables included, classified into five components.

\section{Statistical analysis}

Assessment of each of the five components was performed by means of factor analysis of mixed data 
Table 1 Components and variables used for the characterization of dual-purpose farms

\begin{tabular}{ll}
\hline Component & Numerical variables \\
\hline (1) General Information & Total number of animals; total area, ha; \\
& grazing area, ha; stocking rate, $\mathrm{AU}^{\mathrm{a}} \mathrm{ha}^{-1}$; flat \\
& area, \%; undulated area, \%; hilly area, \%; \\
& agroforestry crops area, ha; perennial crops \\
& area, ha; transitory crops area, ha; forest \\
& monoculture area, ha; improved pastures area, \\
& ha; pasture area with more than 25 trees per \\
& hectare, ha; silvopastoral systems, ha; livestock \\
& area, ha; and number of buffaloes, horses, \\
& mules, pigs, goats, sheep, and hens
\end{tabular}

(2) Herd Composition and Management

(3) Pasture Management

(4) Information on Livestock

Production and Reproduction
Number of milking cows, calved cows, dry cows, female calves (0-1 year old), male calves (0-1 year old), growing females, growing males, breeding heifers, fattening steers, and bulls; supply rate (kg year ${ }^{-1} \mathrm{AU}^{-1}$ ) of mineral salt, supplements, and concentrate feeds

Fertilized area, ha; fertilizer application rate, kg $\mathrm{ha}^{-1}$ year $^{-1}$; and soil amendment application rate, $\mathrm{kg} \mathrm{ha}^{-1}$ year $^{-1}$

Number of milking cows; milk production, L animal $^{-1}$ day $^{-1}$; milk production, $L$ farm ${ }^{-1}$ day $^{-1}$; birth weight, kg; weaning weight, kg; fattening final weight, kg; weaning final age, months; fattening final age, months; weight gain before weaning ${ }^{\mathrm{b}}, \mathrm{kg} \mathrm{day}^{-1}$; weight gain at fattening ${ }^{c}$; and mortality rate, $\%$

\author{
Categorical variables \\ Farm facilities (barn, pen, chute, storehouse), \\ machinery and equipment (tractor, chainsaw, \\ manual lawn mower, motor pump, electric \\ fence, electric pump, electronic scale, cooling \\ tank), crops (agroforestry, perennial, transitory, \\ forest monoculture, scattered trees in pastures, \\ improved pastures, silvopastoral systems), large \\ species (horses and mules), medium-sized \\ species (pigs, goats, and sheep), and small \\ species (chickens) \\ Record keeping (yes, no), mineral salt \\ supplementation (yes, no), plain salt \\ supplementation (yes, no), another kind of \\ supplementation (yes, no), and concentrate \\ feeds (yes, no)
}

Rotational grazing (yes, no), division of paddocks (barbed wire, electric fence, and mixed), weeding method (manual, mechanical, chemical, and mixed), fertilization (yes, no), soil amendments (agricultural lime, dolomite lime), and pasture renewal (yes, no)

Milking method (manual, mechanical), animal weighing method (weighing tape, scale), weighing at birth (yes, no), weighing at weaning (yes, no), reproduction system (free natural mating, controlled natural mating, artificial insemination, embryo transfer), reproductive control on cows and bulls (yes, no), weighing of heifers for breeding at first service (yes, no), inseminator (yes, no), artificial insemination equipment (yes, no), separation of the dry lot (yes, no), calving paddock (yes, no), and determination of the calving interval (yes, no)

Forest (yes, no), water source (surface water, underground water, piped water), water springs (yes, no), water availability during summer for livestock (yes, no), irrigation system (yes, no), wastewater treatment system (yes, no), solid waste management (incineration, burial, water streams, handled by a third party)
(FAMD), using the homonymous function of the FactoMineR package in $R$ ( $R$ Core Team 2016). Mixed data are those in which both quantitative and qualitative variables are recorded on sampling units. FAMD is a multivariate method that simultaneously uses both types of variables as active elements to generate a lowerdimensional space, through the combination of principal component analysis (PCA) and multiple correspondence analysis (MCA) (Pagès 2004). Quantitative variables were balanced and normalized to $Z$ values, whilst the qualitative variables were disaggregated in a disjunctive normalized data table. This ensures a balanced influence of both quantitative and qualitative variables on the determination of the dimensions of the lower-dimensional space. This method allowed us to graphically study similarities/dissimilarities between production units (distances) and correlations between continuous variables (Pagès 2004). Prior to applying FAMD, missing data imputation was carried out, using the algorithm implemented in the imputeFAMD function within the missMDA package (Josse and Husson 2016). Supplementary variables such as the number of animals and producer category did not participate in the construction of the model.

\section{Results}

Table 2 shows the general features (general information and land usage) of the farms. Figures 2, 3, 4, 5 and 6 include a graphic representation of the FAMDs for each of the five components described in Table 1, as well as (a) the spatial relationship amongst the centroids of qualitative variables, with the categories of livestock producers 
Table 2 Biophysical and land-use features in dual-purpose farms by category of livestock producers (average \pm standard deviation)

\begin{tabular}{|c|c|c|c|c|}
\hline Variable & VSP & $\mathrm{SP}$ & MP & $L P$ \\
\hline Total number of producers (percentage of total) & $697(53.1)$ & $211(16.1)$ & $352(26.8)$ & $53(4.0)$ \\
\hline Animals per farm, number & $15 \pm 8$ & $40 \pm 6$ & $103 \pm 46$ & $474 \pm 288$ \\
\hline Total farm area (ha) & $14.5 \pm 25.7$ & $27.7 \pm 25.1$ & $77.0 \pm 114.6$ & $286.3 \pm 384.5$ \\
\hline Livestock area, ha & $14.1 \pm 25.3$ & $27.5 \pm 25.1$ & $76.7 \pm 114.2$ & $285.6 \pm 384.3$ \\
\hline Livestock numbers ( $\mathrm{AU}$ Farm ${ }^{-1}$ ) & $10.6 \pm 5.7$ & $28.4 \pm 4.5$ & $72.1 \pm 33.2$ & $335.1 \pm 202.3$ \\
\hline Livestock numbers $\left(\mathrm{AU} \mathrm{ha}^{-1}\right.$ ) & $1.2 \pm 0.9$ & $1.4 \pm 0.8$ & $1.5 \pm 1.0$ & $1.6 \pm 0.9$ \\
\hline Farms with agroforestry crops (\%) & 2.6 & 0 & 0 & 0 \\
\hline Farm area with agroforestry crops (\%) & $0.6 \pm 5.0$ & - & - & - \\
\hline Farms with perennial crops (\%) & 12.6 & 6.6 & 7.1 & 3.8 \\
\hline Farm area with perennial crops $(\%)^{a}$ & $1.9 \pm 7.0$ & $0.6 \pm 6.4$ & $0.4 \pm 3.5$ & $0.01 \pm 0.04$ \\
\hline Farms with transitory crops (\%) & 11.8 & 9.0 & 8.0 & 5.7 \\
\hline Farm area with transitory crops (\%) & $1.6 \pm 6.8$ & $0.4 \pm 2.5$ & $0.5 \pm 3.5$ & $1.0 \pm 5.7$ \\
\hline Farms with improved pastures (\%) & 48.9 & 39.1 & 34.1 & 37.7 \\
\hline Farm area with improved pastures (\%) & $26.8 \pm 34.4$ & $25.1 \pm 34.9$ & $19.5 \pm 31.8$ & $20.5 \pm 31.4$ \\
\hline Farms with silvopastoral systems (\%) & 2.0 & 3.3 & 2.0 & 9.4 \\
\hline Farm area with silvopastoral systems (\%) ${ }^{a}$ & $0.4 \pm 4.7$ & $0.1 \pm 0.6$ & $0.1 \pm 1.1$ & $1.4 \pm 8.2$ \\
\hline Flat area (\% of total area) & $46.7 \pm 40.2$ & $54.6 \pm 41.0$ & $65.6 \pm 38.9$ & $86.8 \pm 26.9$ \\
\hline
\end{tabular}

$V S P$ very small livestock producers, $S P$ small livestock producers, $M P$ medium livestock producers, $L P$ large livestock producers

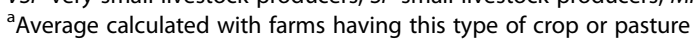

as supplementary variable, and (b) the projection of continuous variables on the factor plane of the first two dimensions with the number of animals as the supplementary variable. Supplementary variables did not participate in the construction of the model. Table S1 of the Supplementary material provides contingency tables of the categorical variables included in the FAMDs. The first two dimensions captured 34.5, 25.1, 30.2, 40.7, and $29.1 \%$ of the variability of components: General
Information about the Farm (Fig. 2), Herd Composition and Management (Fig. 3), Pasture Management (Fig. 4), Production and Reproduction Information (Fig. 5), and Environmental Information (Fig. 6), respectively. The contribution of each variable (square cosine $\left(\cos ^{2}\right)$ ) to the construction of the first two dimensions in each FAMD analysis is presented in Table S2 of the Supplementary material. There was a clear separation of the centroid of the different groups (VSP, SP, MP, and LP)
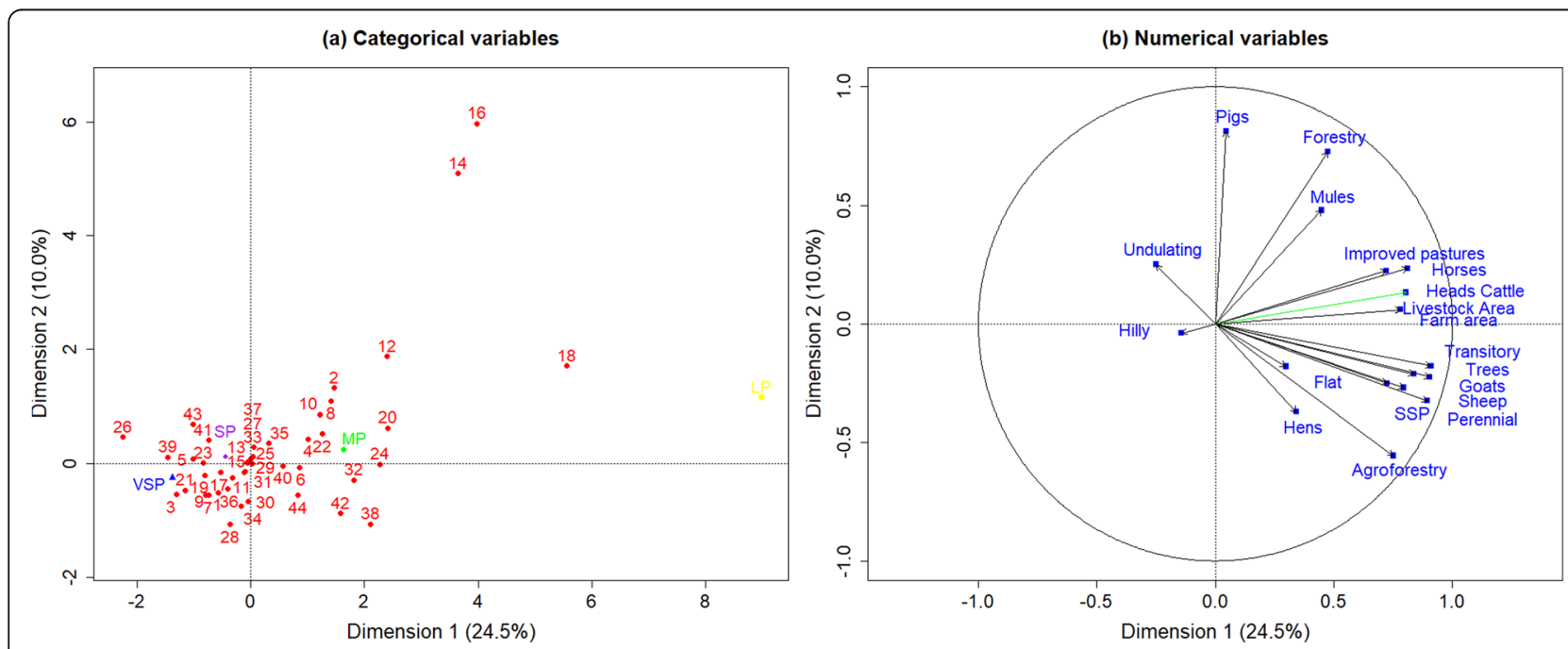

Fig. 2 Spatial projection of $\mathbf{a}$ categorical variables and $\mathbf{b}$ numerical variables for the component General Farm Information. Coding of categorical and numerical variables is shown in Table $\mathbf{3} 3$ of the Supplementary material 

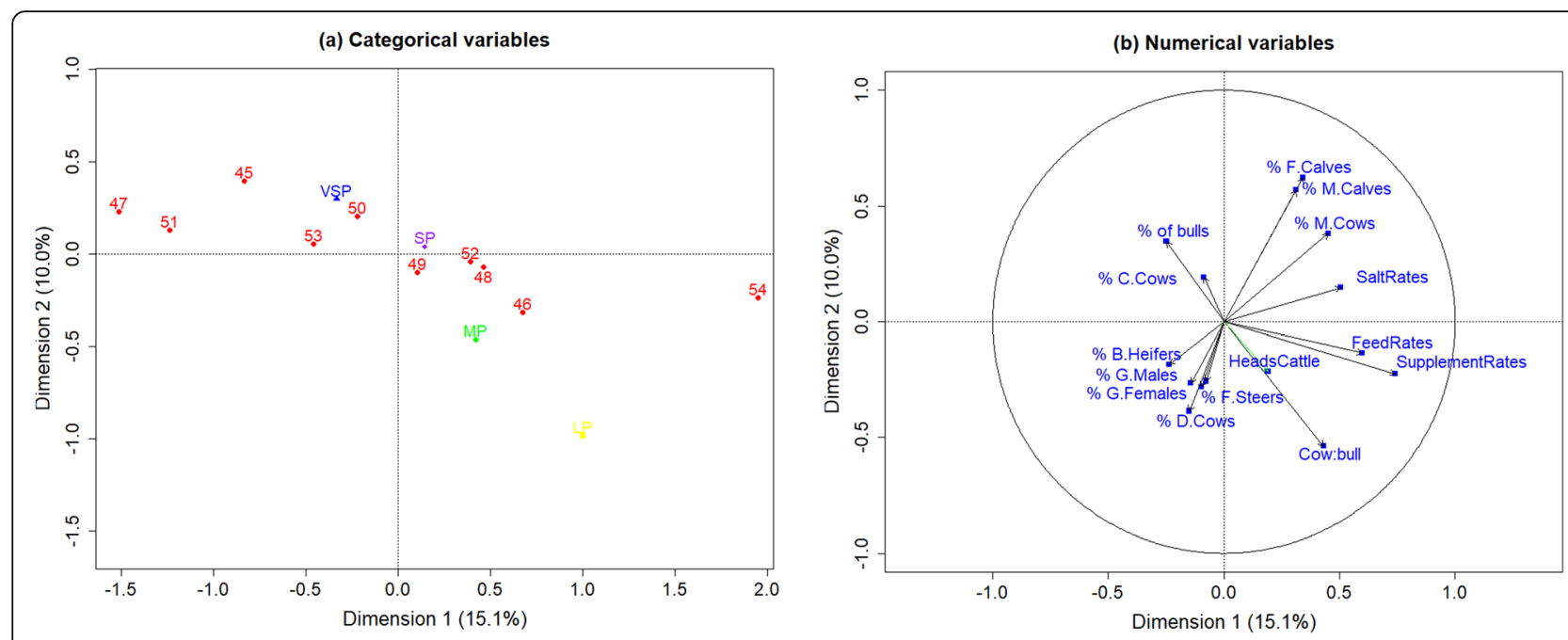

Fig. 3 Spatial projection of a categorical variables and $\mathbf{b}$ numerical variables for the component Herd Composition and Management. Coding of categorical and numerical variables is shown in Table S3 of the Supplementary material

in the components: General Farm Information, Herd Composition and Management, Pasture Management, and Production Information (Figs. 2, 3, 4 and 5). For the component Environmental Information, there was no separation from the centroid, which suggests there are no remarkable differences in the implementation of these practices associated to farm size.

\section{General farm information}

Plotting the categorical variables within this component showed an alignment of the livestock producer categories over the first dimension of the FAMD representation (Fig. 2a) Variables as those related to the presence of machinery, equipment, and facilities were more correlated with the first dimension (tractor, chainsaw, motor pump, manual lawn mower, pen, chute) and second dimension (electronic scale, cooling tank, electric pump, electric fence, barn, and storehouse) (Table S2). In addition, these variables were closely correlated to large-, small-, and medium-sized species, and with categories LP and MP, since they are in the same area of the graph (Fig. 2a). On the contrary, the lack of use of these technologies and the absence of these species were located on the left

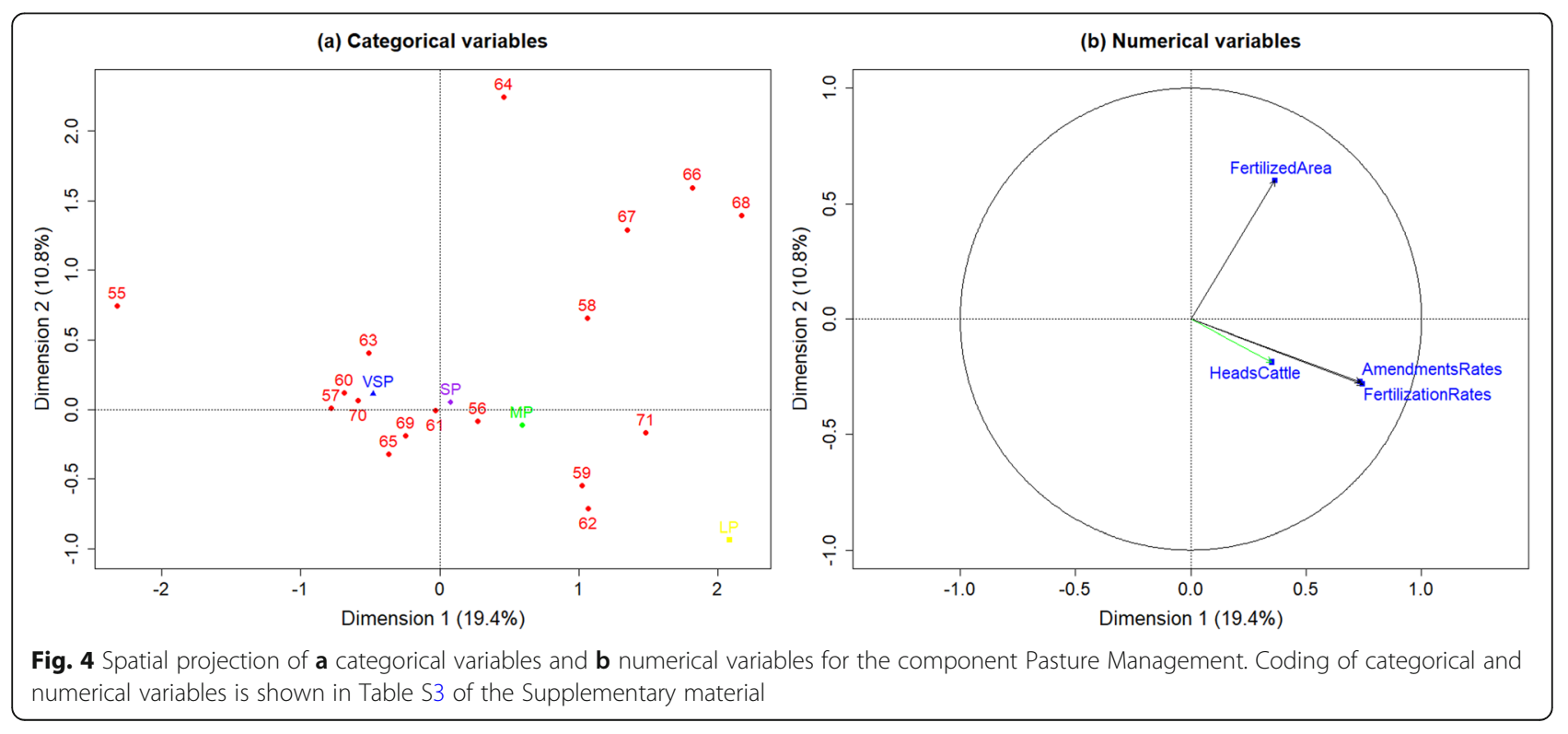



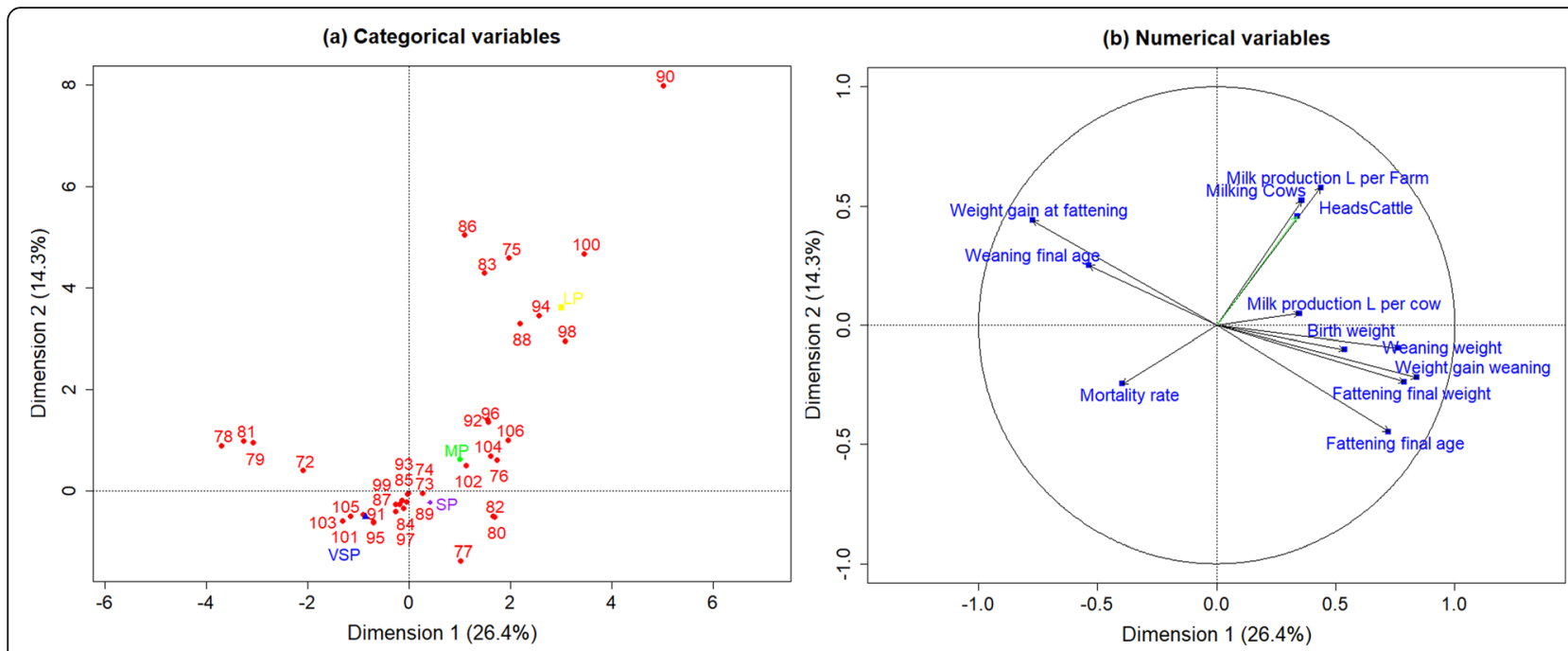

Fig. 5 Spatial projection of a categorical variables and $\mathbf{b}$ numerical variables for the component production and reproduction information. Coding of categorical and numerical variables is shown in Table S3 of the Supplementary material

side of dimension 1, where the presence of agroforestry crops is also located, and are thus associated to categories VSP and SP, as they are in the same area of the graphical plot.

Numerical area variables-total farm area, area allocated to livestock, improved pastures, agroforestry crops, transitory crops (i.e. annual), silvopastoral systems, scattered trees in pastures, and perennial crops-and the number of horses, goats, and sheep contributed the most to the construction of the first dimension (Table S2). Additionally, these variables were positively correlated with this dimension and the number of cattle, i.e. with MP and LP. In turn, the variables number of pigs and forest monoculture were positively correlated and were also the ones contributing the most to the construction of dimension 2 (Table S2).

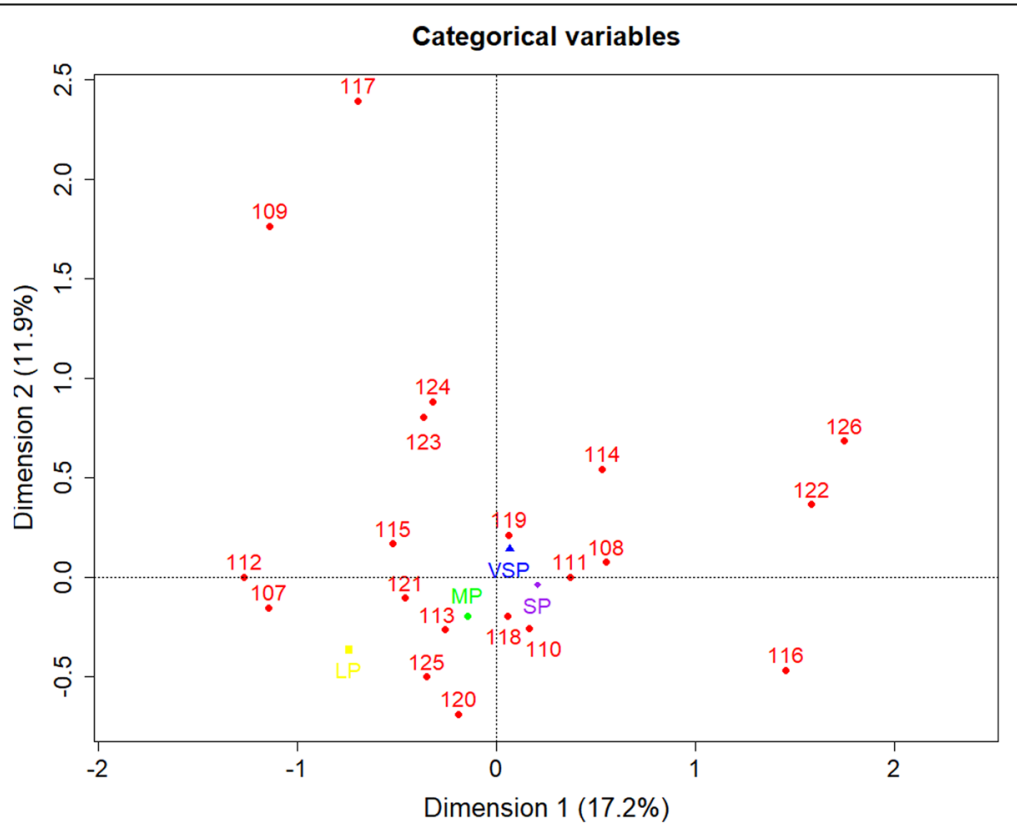

Fig. 6 Spatial projection of $\mathbf{a}$ categorical variables and $\mathbf{b}$ numerical variables for the component Environmental Information. Coding of categorical and numerical variables is shown in Table $\mathbf{3} 3$ of the Supplementary material 
Table 3 Herd composition, supplementary feeding, and productive parameters by farm size for dual-purpose farms (average \pm standard deviation)

\begin{tabular}{|c|c|c|c|c|}
\hline Variable & VSP & SP & MP & $L P$ \\
\hline \multicolumn{5}{|l|}{ Herd composition } \\
\hline Milking cows & $3.2 \pm 3.1$ & $10.1 \pm 5.2$ & $24.0 \pm 16.3$ & $109.1 \pm 91.7$ \\
\hline Calved cows & $0.9 \pm 1.9$ & $1.3 \pm 3.3$ & $2.0 \pm 6.3$ & $10.6 \pm 36.1$ \\
\hline Dry cows & $2.2 \pm 2.6$ & $5.0 \pm 4.5$ & $13.8 \pm 13.4$ & $55.9 \pm 43.1$ \\
\hline Female calves ( $0-1$ year) & $0.6 \pm 0.6$ & $1.6 \pm 1.0$ & $3.8 \pm 2.5$ & $15.9 \pm 14.2$ \\
\hline Male calves ( $0-1$ year) & $0.5 \pm 0.6$ & $1.4 \pm 0.9$ & $3.5 \pm 2.6$ & $15.5 \pm 12.0$ \\
\hline Raising females ( $1-2$ years) & $0.8 \pm 1.5$ & $2.4 \pm 2.6$ & $7.0 \pm 7.6$ & $31.4 \pm 34.4$ \\
\hline Raising males ( $1-2$ years) & $0.5 \pm 1.2$ & $1.3 \pm 2.3$ & $4.4 \pm 6.1$ & $27.8 \pm 37.3$ \\
\hline Heifers for breeding ( $2-3$ years) & $1.3 \pm 2.4$ & $3.7 \pm 5.3$ & $8.6 \pm 10.9$ & $37.8 \pm 39.8$ \\
\hline Fattening calves ( $2-3$ years) & $0.3 \pm 1.4$ & $0.7 \pm 3.1$ & $3.2 \pm 8.4$ & $20.0 \pm 38.4$ \\
\hline Bulls & $0.7 \pm 1.1$ & $1.4 \pm 1.4$ & $2.7 \pm 2.2$ & $11.3 \pm 10.8$ \\
\hline \multicolumn{5}{|l|}{ Supplementary feeding } \\
\hline Supply rate of concentrate feeds $\left(\mathrm{kg} \text { year }{ }^{-1} \mathrm{AU}^{-1}\right)^{\mathrm{a}}$ & $228.1 \pm 85.9$ & $235.5 \pm 91.2$ & $307.4 \pm 96.4$ & $310.7 \pm 105.9$ \\
\hline Supply rate of supplements $\left(k \text { year }{ }^{-1} \mathrm{AU}^{-1}\right)^{\mathrm{a}}$ & $76.0 \pm 32.2$ & $73.1 \pm 31.4$ & $84.7 \pm 38.9$ & $95.4 \pm 41.3$ \\
\hline Supply rate of mineral salt $\left(\mathrm{kg} \mathrm{year}^{-1} \mathrm{AU}^{-1}\right)^{\mathrm{a}}$ & $29.2 \pm 13.8$ & $31.8 \pm 7.9$ & $33.3 \pm 4.9$ & $33.6 \pm 1.7$ \\
\hline \multicolumn{5}{|l|}{ Productive parameters } \\
\hline Weight at birth (kg) & $32.4 \pm 4.5$ & $32.6 \pm 4.4$ & $32.3 \pm 4.4$ & $33.0 \pm 4.0$ \\
\hline Weight at weaning $(\mathrm{kg})$ & $139.1 \pm 24.9$ & $141.9 \pm 23.1$ & $154.6 \pm 25.1$ & $150.8 \pm 24.4$ \\
\hline Age at weaning (months) & $8.2 \pm 1.4$ & $8.2 \pm 1.2$ & $8.6 \pm 1.1$ & $8.8 \pm 0.9$ \\
\hline LWG pre-weaning stage $^{\mathrm{b}}\left(\mathrm{kg} \mathrm{day}^{-1}\right)$ & $0.45 \pm 0.12$ & $0.45 \pm 0.10$ & $0.48 \pm 0.11$ & $0.45 \pm 0.09$ \\
\hline LWG fattening stage $\left(\mathrm{kg} \mathrm{day}^{-1}\right)$ & $0.41 \pm 0.07$ & $0.42 \pm 0.07$ & $0.43 \pm 0.10$ & $0.47 \pm 0.08$ \\
\hline Mortality rate (\%) & $11.3 \pm 11.8$ & $9.1 \pm 10.6$ & $5.6 \pm 5.7$ & $3.0 \pm 2.1$ \\
\hline Milk production $\left(\mathrm{L} \mathrm{cow}^{-1}\right.$ day $\left.^{-1}\right)$ & $3.2 \pm 2.2$ & $3.8 \pm 1.7$ & $3.7 \pm 1.4$ & $3.7 \pm 1.1$ \\
\hline
\end{tabular}

VSP very small livestock producers, $S P$ small livestock producers, $M P$ medium livestock producers, $L P$ large livestock producers, $A U$ animal units, $L W G$ live weight gain

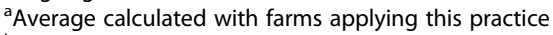

${ }^{\mathrm{b}}$ Average daily weight gain before weaning

\section{Herd composition and management}

Herd composition, supply rates of supplementary feeds, and productive and reproductive parameters for VSP, SP, MP, and LP are shown in Table 3. Calved cows are those calved in the days prior to the development of the surveys, whilst milking cows are those which are milked and usually have a calf with her until the weaning. After a period of time, when calved cows start to be milked, they are counted as milking cows.

Analysis of the categorical variables showed a higher correlation in the use of concentrate feeds, mineral salts, and record keeping for livestock production with dimension 1 (Table S2). Variables indicating the adoption of these practices were located on the right side of the first dimension, whilst variables indicating non-adoption were located on the left side (Fig. 3a). Therefore, MP and LP are more likely to keep productive and reproductive records and use a larger proportion of supplementary feed in the animal diets than VSP and SP (Table S1).
Regarding numerical variables, the supply rate of mineral salts, concentrate feeds, and supplementary feeds showed a positive correlation to dimension 1 (Fig. 2b) (Table S2). On the other hand, variables such as the percentage of male and female calves and the percentage of milking cows showed a positive correlation with dimension 2 (Table S2).

\section{Pasture management}

Categorical variables such as pasture renovation, rotational grazing, chemical fertilization, division of paddocks with barbed wire, and manual weed control presented a higher correlation with dimension 1 (Fig. 4a) (Table S2). On the other hand, chemical and mixed weed control and no use of soil amendments had a higher correlation with the second dimension (Table S2). Additionally, there was an aggregation towards the right side of dimension 1 of the variables: chemical fertilization, pasture renovation, rotational grazing, 
division of paddocks, application of soil amendments, and use of electric fences (Fig. 4a). On the contrary, variables related to the non-implementation of these practices and/or activities oriented towards the left side of dimension 1. Moreover, as an overall behaviour, MP and LP tend to divide pastures using electric fences and barbed wire (the combination of both practices) to a larger extent, as well as weed control using a combination of chemical, mechanical, and manual methods (mixed method), and pasture renewal practices.

Numerical variables, such as fertilization rate, application of soil amendments, and number of animals, were positively correlated to dimension 1 (Fig. $4 \mathrm{~b}$ ). On the other hand, fertilized area was positively correlated to dimension 2 (Table S2). This suggests that MP and LP applied higher amounts of fertilizers and soil amendments.

\section{Production and reproduction information}

With respect to the categorical variables, the use of a scale, weighing animals, weighing at birth and weaning, calving paddock, determination of the calving interval, and separation of the dry lot showed a high correlation with dimension 1 (Table S2). In addition, variables such as type of reproduction system, weighing measuring tape, and reproductive control on cows and bulls presented high correlation with dimension 2 (Table S2). Furthermore, there was an aggregation towards the upper side of the graph of the categorical variables: mechanical milking, controlled natural mating, artificial insemination, embryo transfer, palpation of cows, reproductive control on bulls, weighing of heifers for breeding at first service, the use of scale, separation of the dry lot, and determination of the calving interval, in addition to the existence of a calving paddock, equipment for artificial insemination, and inseminator (Fig. 5a). On the contrary, the variables related to non-adoption of these practices and/or activities, and the non-existence of such facilities or equipment were located on the left side of the graph, along with the variable free natural mating. Hence, both MP and LP tend to carry out better productive and reproductive practices, which could lead to a better economic performance of farms classified in those categories (Holmann et al. 2003).

With respect to numerical variables, live weight gain (LWG) in the pre-weaning stage, weight at weaning, weight at birth, final fattening weight, and age at the end of fattening showed a positive correlation to dimension 1 (Table S2) (Fig. 5b). Moreover, age at weaning, LWG in the fattening stage, and mortality rate showed a negative correlation to dimension 1 . In addition, the number of milking cows, total milk production $\left(\mathrm{L} \mathrm{farm}^{-1} \mathrm{day}^{-1}\right.$ ), and the number of animals were positively correlated to dimension 2 .

\section{Environmental information}

In this component, there was no clear separation of the centroid amongst the four livestock producer categories (Fig. 6), which suggests there are no patterns in the development and implementation of environmental practices across producer categories.

\section{Discussion}

Around $69.2 \%$ of the surveyed farms had less than 50 animals, which agrees with the percentage distribution of livestock farms in Colombia (ICA 2019). Similarly, over 50\% of dual-purpose cattle systems characterized in Mexico corresponded to small farmers with less than 50 animals (Vilaboa-Arroniz and Díaz-Rivera 2009; Orantes-Zebadúa et al. 2014). Therefore, to have an impact on most producers and improve their economic and social conditions, public policies to promote and transfer technology in the country should include VSP and SP. However, for greater impact on DPS as a whole, attention should also be paid to MPwhich account for $27 \%$ of farms but own $45 \%$ of the total cattle population of the farms-for development of strategies to improve production.

\section{General farm information}

VSP and SP, where the use of family labour prevails, were related to lower availability and existence of machinery, equipment, and facilities, compared to MP and LP (Table S1). However, this was not reflected in higher productivity of bigger farms. In addition, it has been reported that investments on infrastructure and equipment are marginal in DPS in Colombia, because they are systems with low levels of specialization and, in general, investments are mainly done on land and cattle (Rivas and Holmann 2002). The foregoing, in addition to the low percentage of farm area with flat topography (Table 2) means that smaller producers who have poor access to finances have restricted possibility of investing in machinery or equipment. Similar observations were reported in characterizations of DPS in Bolivia, Colombia, and Mexico, where small- and medium-sized producers showed a low availability of machinery, equipment, and infrastructure for cattle production (Solano et al. 2000; Cortés-Mora et al. 2012; Cuevas-Reyes and Rosales-Nieto 2018; Méndez-Cortés et al. 2019). Therefore, the majority of DPS in Colombia and Latin America as a whole, which are small farmers, usually have limited adoption of technologies, and farm operations are dependent on family labour.

In all categories of livestock producers, the share of farms with agroforestry, transitory (annual), and perennial crops was below 13\%, which indicates that DPS follow a simplified livestock production approach, based on monocultures without crop diversification. Thus, as long as DPS have the necessary area, they could offer a major 
potential to diversify production, for instance, through the incorporation of agricultural and forestry systems. The livestock, agricultural, and forestry diversification in cattle farms could generate productive and environmental benefits (Iglesias et al. 2011). Agroforestry systems (AFS) are an alternative that makes it possible to diversify and optimize production and increase the productive and environmental parameters of DPS. Within AFSs, trees or shrubs interact biologically and economically with crops and animals in the same area, associated either simultaneously or sequentially (Sotelo et al. 2017). Additionally, AFS farms can be more stable and resilient to climate impacts, which makes them an important alternative to mitigate and adapt to climate change and generate ecosystem services. However, the implementation of AFS has to be evaluated specifically for each farm according to their characteristics, the willingness of ranchers to adopt this technology, and the financial mechanisms for its adoption, amongst others.

\section{Herd composition and management}

MP and LP showed larger supplementation rates of external feed inputs (Table 3). Supplementation with mineral salt is a widely adopted practice in the DPS and is being conducted in over 73\% of farms assessed in each category (Table S1). Similar results have been reported for DPS in Colombia, where mineral supplementation was carried out in most of the characterized herds (Cortés-Mora et al. 2012, 2014). This type of supplement could make it possible to offset the possible mineral deficiencies of natural pastures usually present in extensive systems (Rosero-Noguera and Posada-Ochoa 2016), and improve the productive and reproductive parameters of the herd. However, with the data available, it was not possible to assess how the supplementation with mineral salt is impacting the productive parameters of farms, but it is expected that the impact could be positive.

The use of concentrate feeds was more associated to MP and LP; however, the percentage of farms supplying them was lower than $41 \%$ in all categories, with the highest numbers occurring in MP (40\%) and LP (41\%). These results are similar to those reported in characterizations of DPS in Mexico and Bolivia, where the use of concentrate feeds was low, and mainly amongst the smaller producers (Solano et al. 2000; Rangel et al. 2017, 2020; Cuevas-Reyes and Rosales-Nieto 2018; MéndezCortés et al. 2019). Nevertheless, our results were higher than those reported in a project conducted in Colombia, where characterized DPS did not use any concentrate feeds (Cortés-Mora et al. 2012), but this study was performed for a small sample of 14 farms from a specific region of the country which did not adequately represent DPS at the national level. It has been reported that the highest variable expenses in intensive cattle herds are usually attributable to the supplementary feeds (Fedegan 2013a). The high cost of supplementation and the possible low economic return to farmers could explain the low adoption rate of this practice in the studied DPS, as was also reported in characterizations carried out in Colombia and Mexico (Fedegan 2013b; OrantesZebadúa et al. 2014).

In the four livestock producer categories, the percentages of cows in the herd ranged between $53 \%$ to $60 \%$, whilst the percentage of male and female calves $(0-1$ year) was 6 and 5\%, respectively. The percentage of milking cows showed a positive relationship with the percentage of female and male calves ( $0-1$ year) (Fig. $2 b)$. Similar observations were reported for DPS in Mexico where most of the herd corresponded to cows, heifers, and female calves (Vilaboa-Arroniz and Díaz-Rivera 2009; Albarrán-Portillo et al. 2015). The above shows that studied DPS farms are mostly oriented towards milk production as the main productive and economic activity, with meat as a co-product on the farms, which agrees with other studies conducted on DPS farms in Colombia (Holmann et al. 2003; Cortés-Mora et al. 2012). Therefore, a dual-purpose system is an important modality of milk production in the country, due to DPS being approximately $39 \%$ of the national cattle population (DANE 2017). However, milk yield per cow is much lower than figures reported for specialized dairy systems in Colombia (Múnera-Bedoya et al. 2018; Ruiz et al. 2019). Hence, this characterization study can help policymakers to know the strengths and weaknesses of DPS, for proposing strategies to improving the performance of these systems, and therefore strengthen the national dairy market.

Higher rates of adoption of practices such as record keeping were found among SP (62\%), MP (74\%), and LP (91\%), whilst only $41 \%$ of VSP carried out this activity. The aforementioned result contrasts with the study of Cortés-Mora et al. (2012) and Solano et al. (2000) in Colombia and Bolivia, respectively, where most characterized DPS farms did not implement any record keeping. The lack of records could limit the proper establishment of plans for improving efficiency and profitability. Hence, we suggest that promoting a culture of record keeping in all farms could help ensure the success of technical assistance and technology transfer, by monitoring of productive, reproductive, and economic parameters on farms (Díaz-Castillo et al. 2014).

\section{Pasture management}

In all the four categories, farms tend to have low proportions of their areas with improved pastures (values ranging between 34 and $49 \%$ ), as was also reported for DPS in Latin America as a whole (Solano et al. 2000; Rangel et al. 2020). In addition, the percentage adopting 
chemical fertilization was also low in each farm category, with values ranging between 16 and $18 \%$. These findings are similar to those reported for DPS in Latin America, in which adoption percentages were low or zero (Urdaneta de Galué et al. 2008; Bravo et al. 2018; Enciso et al. 2018). Therefore, there were more farms adopting improved pastures than farms implementing chemical fertilization. It has been reported that pasture yield is usually increased by using $\mathrm{N}$ fertilizer (Macdonald et al. 2017); hence, the lack of pasture fertilization in the farms with improved pastures affects the total forage production and likely their milk and meat production.

Our findings also showed that chemical fertilization rates on pastures ranged between 120 and $360 \mathrm{~kg} \mathrm{~N} \mathrm{ha}^{-1}$ year $^{-1}$, and the highest rates corresponded to LP. Among DPS in the Latin American tropics, adoption of chemical fertilization is not a common practice, and is mostly adopted by large farmers with application rates below 100 $\mathrm{kg} \mathrm{ha}^{-1}$ (Urdaneta de Galué et al. 2008). There is variability in the application rates of fertilizer amongst DPS. Therefore it is necessary to establish optimal fertilization rates by evaluating the economic and productive responses to different doses, taking into account soil properties, climatic condition, type of pastures, and type of production system implemented, amongst other characteristics. This could help to increase the performance of farms, avoiding overgrazing and guaranteeing the system's sustainability.

Regardless of the method used, weed control was performed in over $90 \%$ of farms across the livestock producer categories, which highlights the importance that farmers attach to weed control. The manual method was the most widely used by VSP (57\% of farms) and SP (52\%), whilst the mixed method (manual, mechanical, and chemical) was used by MP (51\%) and LP (72\%). This behaviour was also reported for DPS in Central America, where most farms did not use herbicides, machinery or equipment for controlling weeds, and predominantly used manual controls (Yamamoto et al. 2007; Ferguson et al. 2013; Gaitán et al. 2016). The above finding, added to the high percentages of farms that did not adopt pasture fertilization or supplementary feeds, indicates the low dependence on external inputs among the majority of DPS studied, which is common in the Latin American context.

Rotational grazing was more practiced by MP and LP, with larger percentages of adoption (96 and 100\%, respectively); however, this was a common practice across all categories, carried out in over $85 \%$ of farms. This good pasture management practice is important because it can help to reduce the impact of cattle on the soil and allow for the recovery of pastures and shrubs during the resting periods (Calle et al. 2012). The foregoing can also benefit the quantity and quality of biomass production, prevent pasture degradation, and improve the productive parameters of the herd (Arango et al. 2016).

\section{Production and reproduction information}

In the four livestock producer categories, the most widely used reproduction method was free natural mating (Table S1). This is in agreement with characterizations of cattle farms in Latin America as a whole, indicating a low technological level in use of reproduction methods such as artificial insemination or embryo transfer (Solano et al. 2000; Cortés-Mora et al. 2012; Rangel et al. 2017, 2020; Nieto et al. 2018). However, it is important to note that LP (34\%) practised artificial insemination (AI) to a larger extent than the rest of the livestock producer categories. This could reflect a greater economic capacity and better technical assistance service for these farmers, as reported in other cattle systems in Latin America, where larger ranchers who showed greater economic returns and more intensive farms adopted this reproductive method (Solano et al. 2000; Cuevas-Reyes et al. 2013; Mazzetto et al. 2015). It has been reported that the adoption of artificial insemination improves the reproductive parameters of farms, such as increasing conception rate up to 70\% (Mazzetto et al. 2015). Therefore in future studies it is necessary to evaluate how the adoption of AI could influence reproductive and productive performances of DPS in Colombia, to define the viability of AI adoption.

Mortality rates were inversely correlated to the number of cattle (Fig. 5b) and were higher in VSP and SP, compared to MP and LP (Table 3). A higher mortality rate generates less profitability and competitiveness for the farm, which in turn can lead to lower income for VSP and SP. In addition, it must be kept in mind that in small farms, the proportional impact of one dead animal is greater than in a big farm.

Milk production ranged between 3.2 and $3.8 \mathrm{~L} \mathrm{cow}^{-1}$ day $^{-1}$ across all four livestock producer categories. This yield falls within the range reported for DPS in Colombia, where the average yield is $3.5 \mathrm{~L} \mathrm{cow}^{-1}$ day $^{-1}$ and higher at $6.8 \mathrm{~L} \mathrm{cow}^{-1}$ day $^{-1}$ in more intensified farms (Fedegan 2013b). In addition, our results are similar to those reported for conventional DPS in Bolivia and Nicaragua (Solano et al. 2000), higher than smallholder DPS farms in Mexico (Rangel et al. 2020), but lower than figures for intensified DPS farms in Mexico and Nicaragua (Ferguson et al. 2013; Albarrán-Portillo et al. 2015; Gaitán et al. 2016).

Results for weight at weaning (139.1-154.6 kg) and age at weaning (8.2-8.8 months) in all four farm categories were similar to the values reported for conventional DPS in Colombia and Mexico (Rojo-Rubio et al. 2009; VillateCalderón and Martínez-Roldán 2011; Orantes-Zebadúa et al. 2014; Bravo et al. 2018; Enciso et al. 2018). The higher weight at weaning observed in MP and LP was influenced by older age and not by the daily weight gain at this stage (Table 3). The results for the LWG in the pre- 
weaning stage were higher than the national average reported by Fedegan (2013b) for DPS, where the age at weaning varied from 8 to 9.5 months and daily weight gain (DWG) ranged between 0.15 and $0.35 \mathrm{~kg}$. However, these parameters are low, compared to intensified DPS, where the reported DWG was $0.57 \mathrm{~kg}$ (Fedegan 2013b). Intensified DPS were characterized by developing good livestock management practices, which led to higher economic and productive (milk or beef per unit area and/or per animal) indicators than the national average (Fedegan 2013b). The above results point out that adoption of good livestock practices, and the intensification of farms through supplementary feed and improved pastures, can be strategies for increasing productivity performance of farms in terms of milk and meat yields.

\section{Environmental information}

The main solid waste management practice was incineration, with adoption rates above $56 \%$ in each livestock producer category (Table S1). Burial of solid waste was the second most used management practice in all four producer categories (21-26\%), whilst the delivery of solid waste to third parties was observed in less than $20 \%$ of farms. These management practices were also reported as the most used by DPS in Colombia, where incineration and burial were implemented in $64 \%$ of characterized farms, due to a lack of solid waste collection service in rural areas (Cortés-Mora et al. 2012).

Over $64 \%$ of all farmers reported the presence of forests on their farms (Table S1); however, it was not determined what percentage of the farm area was allocated to this land use. Therefore, it is necessary to promote the conservation of existing forests in cattle farms and, if possible, increasing the forested area, to ensure conservation of different tree and shrub species, foster biodiversity, protect water sources, provide animals with shade, increase connectivity, and improve the physical and chemical characteristics of the soil, amongst other benefits.

The implementation of wastewater treatment systems in the four farm categories was below $40 \%$, which is similar to the information reported for DPS in Colombia, where less than $30 \%$ of farms implemented this type of technology (Cortés-Mora et al. 2012). Livestock farming can contribute to the eutrophication of water sources through the release of nutrients, pathogens, pesticides, antibiotics, and heavy metals (PatiñoMurillo and Tobasura-Acuña 2011). Considering that over $85 \%$ of farms used surface water bodies as their source of water supply, both for household and farming use, it is important to establish mechanisms for the implementation of wastewater treatment systems, to prevent eutrophication and ensure a better quality of water supply for human and animal consumption.

\section{Conclusions}

Our findings show that, in general, medium-sized and large farms were associated with better infrastructure, better machinery and equipment, and better reproductive practices. However, this was not reflected in a significant improvement of productive parameters, except for a lower mortality rate. Therefore, based on the available infrastructure and better livestock management practices developed, larger livestock producers need to better plan their livestock activity, with the purpose of increasing their productivity.

The main features identified for each livestock producer category can guide and establish policies and programmes for their technological improvement. The development of better livestock management practices and the adoption of more technology, as well as technical assistance, should focus on small- and mediumsized livestock producers, which could lead to better productive and reproductive performance of dualpurpose systems.

There were no big differences in the implementation of environmental practices associated with the size of the farms. It is important that future research studies obtain more information on the environmental features of farms, to allow for quantification of impacts and development of strategies to mitigate negative impacts.

\section{Supplementary information}

Supplementary information accompanies this paper at https://doi.org/10. 1186/s13570-020-00170-5.

Additional file 1: Table S1. Contingency table for the categorical variables included in the FAMD analysis of each component evaluated. Table S2. Contribution of each variable to the construction of the first two dimensions in each FAMD analysis in terms of Square Cosine. Table S3. Coding of categorical and numerical variables by component.

\section{Abbreviations \\ AFS: Agroforestry systems; AU: Animal unit; $\operatorname{Cos}^{2}$ : Square cosine; DPS: Dual- purpose cattle systems; DWG: Daily weight gain; FAMD: Factor analysis of mixed data; GCS: Sustainable Colombian Cattle Ranching; L+: LivestockPlus; LP: Large livestock producers; LWG: Live weight gain; MCA: Multiple correspondence analysis; MP: Medium livestock producers; PCA: Principal component analysis; SP: Small livestock producers; VSP: Very small livestock producers}

\section{Acknowledgements \\ This study is part of the LivestockPlus project funded by the CGIAR Research Program (CRP) on Climate Change, Agriculture and Food Security (CCAFS). In addition, this work was also done as part of the Livestock CRP. We thank all the donors that globally support the work of the CRP programmes through their contributions to the CGIAR System. We are thankful to the Colombian Sustainable Cattle Ranching Project implemented by the Federación Colombiana de Ganaderos (Fedegan-FNG), the Fundation Centro para la Investigación en Sistemas Sostenibles de Producción Agropecuaria (CIPAV), the Fondo Acción, and The Nature Conservancy (TNC).}

Authors' contributions

RGQ conceptualization, funding acquisition, data curation, formal analysis, investigation, methodology, software, visualization, writing - original draft \& editing. RBR conceptualization, supervision, funding acquisition, visualization, 
writing - review \& editing. DMBV data curation, validation, writing - review \& editing. NC and JA project administration, funding acquisition, writing review \& editing. HAP funding acquisition. GCL data curation, formal analysis, methodology, software. MSSP conceptualization, supervision, visualization, writing - review \& editing. The author(s) read and approved the final manuscript.

\section{Funding}

This work was supported by the Global Environmental Fund (GEF), CGIAR Fund Donors and through bilateral funding agreements (for details please visit https://ccafs.cgiar.org/donors), and MINCIENCIAS (call 727 of 2015).

\section{Ethics approval and consent to participate}

Not applicable.

\section{Consent for publication}

Not applicable.

\section{Competing interests}

The authors declare that they have no competing interests.

\section{Author details}

${ }^{1}$ International Center for Tropical Agriculture (CIAT), Km 17 recta Cali, Palmira, Valle del Cauca, Colombia. ${ }^{2}$ Facultad de Ciencias Agrarias, Universidad de Antioquia, Carrera 75 \# 65-87 bloque 47, office 231, Medellin, Colombia. ${ }^{3}$ Facultad de Ciencias Agrarias, Universidad Nacional de Colombia sede Medellín, Medellin, Colombia. ${ }^{4}$ Mohammed VI Polytechnic University (UM6P), AgroBioSciences (AgBS), Agricultural Innovations and Technology Transfer Centre (AITTC), Benguerir, Morocco. ${ }^{5}$ Federación Colombiana de Ganaderos (FEDEGAN), Calle 37 \# 14-31, Bogota, Colombia. ${ }^{6}$ Compañía Nacional de Chocolates, Km 2-Vía Autopista Medellín-Bogotá, Rionegro, Antioquia, Colombia.

Received: 10 January 2020 Accepted: 24 April 2020

Published online: 07 September 2020

\section{References}

Albarrán-Portillo, B., S. Rebollar-Rebollar, A. García-Martínez, R. Rojo-Rubio, F. Avilés-Nova, and C.M. Arriaga-Jordán. 2015. Socioeconomic and productive characterization of dual-purpose farms oriented to milk production in a subtropical region of Mexico. Tropical Animal Health and Production 47: 519523. https://doi.org/10.1007/s11250-014-0753-8 Kluwer Academic Publishers.

Arango, J, JF Gutiérrez, J Mazabel, P Pardo, K Enciso, S Burkart, M Sotelo, et al. 2016. Estrategias Tecnológicas para Mejorar la Productividad y Competitividad de la Actividad Ganadera: Herramientas para Enfrentar el Cambio Climático. CIAT No. 414

Bravo, A., K. Enciso, J.J. Hurtado-Bermúdez, J.R. del Cairo, M. Jager, A. Charry, M.A. Romero Sanchez, L. Sierra, M. Quintero, and S. Burkart. 2018. Estrategia sectorial de la cadena de ganadería doble propósito en Guaviare, con enfoque agroambiental y cero deforestación. Edited by Publicación CIAT No. 454. Cali: Centro Internacional de Agricultura Tropical.

Calle, Z., E. Murgueitio, and J. Chará. 2012. Integración de las actividades forestales con la ganadería extensiva sostenible y la restauración del paisaje. Unasylva 63: 31-40.

Cortés-Mora, J.A., A. Cotes-Torres, and J.M. Cotes-Torres. 2012. Características estructurales del sistema de producción con bovinos doble propósito en el trópico húmedo colombiano. Revista Colombiana de Ciencias Pecuarias 25: 229-239.

Cortés-Mora, J.A., A. Cotes-Torres, and J.M. Cotes-Torres. 2014. Avances en clasificación de sistemas de producción con bovinos doble propósito en Colombia. Archivos de zootecnia 63: 559-562.

Cuevas-Reyes, V., J. Baca-del Moral, F. Cervantes-Escoto, J.A. Espinosa-García, J. Aguilar-Ávila, and A. Loaiza-Meza. 2013. Factores que determinan el uso de innovaciones tecnológicas en la ganadería de doble propósito en Sinaloa, México. Revista Mexicana De Ciencias Pecuarias 4: 31-46.

Cuevas-Reyes, V., and C. Rosales-Nieto. 2018. Caracterización del sistema bovino doble propósito en el noroeste de México: productores, recursos y problemática. Revista MVZ Córdoba 29: 50-56. https://doi.org/10.21897/rmvz. 1240.
DANE. 2017. Encuesta Nacional Agropecuaria 2016. Bogotá D.C. https://www.dane. gov.co/index.php/estadisticas-por-tema/agropecuario/encuesta-nacionalagropecuaria-ena.

Díaz-Castillo, A., Y. Sardiñas-López, E. Castillo-Corría, C. Padilla-Corrales, H. JordánVázquez, R.O. Martínez-Zubiaur, T.E. Ruiz-Vázquez, M.F. Díaz-Sánchez, A.F. Moo-Cruz, and O. Gómez-Cruz. 2014. Caracterización de ranchos ganaderos de Campeche, México. Resultados de proyectos de transferencia de tecnologías. Avances en Investigación Agropecuaria 18: 41-61.

Enciso, K., A. Bravo, A. Charry, G. Rosas, M. Jäger, J.J. Hurtado, M. Romero, L. Sierra, M. Quintero, and S. Burkart. 2018. Estrategia sectorial de la cadena de ganadería doble propósito en Caquetá, con enfoque agroambiental y cero deforestación. Edited by Publicación CIAT No. 454. Cali: Centro Internacional de Agricultura Tropical.

FAO. 2013. FAOSTAT. Agricultural Production. http://faostat3.fao.org/home/E.

Fedegan. 2006. Plan estratégico de la ganadería colombiana 2019 - Por una ganadería moderna y solidaria. Vol. 1. Bogotá: PEGA 2019 978-958-98018-1-9.

Fedegan. 2013a. Costos modales en ganadería de leche - trópico alto de Colombia Ventana a la competitividad ganadera. Bogotá: Federación Colombiana de Ganaderos.

Fedegan. 2013b. Costos y los indicadores de productividad en la ganadería colombiana. In Foro empresarización y competitividad ganadera, ed. Bogotá: Federación Colombiana de Ganaderos.

Fedegan, 2019. Estadísticas. Bogotá: Federación Colombiana de Ganaderos. https://www.fedegan.org.co/estadisticas/estadisticas.

Ferguson, Bruce G., Stewart A.W. Diemont, Rigoberto Alfaro-Arguello, Jay F. Martin, José Nahed-Toral, David Álvarez-Solís, and René Pinto-Ruíz. 2013. Sustainability of holistic and conventional cattle ranching in the seasonally dry tropics of Chiapas, Mexico. Agricultural Systems 120: 38-48. https://doi. org/10.1016/j.agsy.2013.05.005 Elsevier.

Gaitán, Lucía, Peter Läderach, Sophie Graefe, Idupulapati Rao, and Rein van der Hoek. 2016. Climate-smart livestock systems: An assessment of carbon stocks and GHG emissions in Nicaragua. PLoS One 11. https:/doi.org/10.1371/journal.pone.0167949.

Holmann, F., Rivas, L., Carulla, J., Giraldo, L., Guzman, S., Martinez, M., Rivera, B., Medina, A., Farrow, A. 2003. Evolución de los Sistemas de Producción de Leche en el Trópico Latinoamericano y su interrelación con los Mercados: Un Análisis del Caso Colombiano. Cali: Centro Internacional de Agricultura Tropical.

ICA. 2019. Censo Pecuario Nacional 2019. Bogotá.

Iglesias, J.M., F. Funes-Monzote, Odalys C. Toral, L. Simón, and M. Milera. 2011. Pastos y Forrajes. Pastos y Forrajes 34: 241-257.

Josse, J., and F. Husson. 2016. missMDA: A package for handling missing values in multivariate data analysis. Journal of Statistical Software 70: 1-31. https:// doi.org/10.18637/jss.V070.101.

Macdonald, K.A., J.W. Penno, J.A.S. Lancaster, A.M. Bryant, J.M. Kidd, and J.R. Roche. 2017. Production and economic responses to intensification of pasture-based dairy production systems. Journal of Dairy Science 100: 66026619. https://doi.org/10.3168/jds.2016-12497 Elsevier Inc.

Magaña-Monforte, J.G., G. Ríos-Arjona, and J.C. Martínez-González. 2006. Los sistemas de doble propósito y los desafíos en los climas tropicales de México. Archivos Latinoamericanos de Producción Animal 14: 105-114.

Mazzetto, A.M., B.. Feigl, R.L.M. Schils, C.E.P. Cerri, and C.C. Cerri. 2015. Improved pasture and herd management to reduce greenhouse gas emissions from a Brazilian beef production system. Livestock Science 175: 101-112. https:/doi.org/10.1016/j/livsci.2015. 02.014 .

Méndez-Cortés, Vianeth, José Saturnino Mora-Flores, José Alberto García-Salazar, Omar Hernández-Mendo, Roberto García-Mata, and Roberto Carlos GarcíaSánchez. 2019. Tipología de productores de ganado bovino en la zona norte de Veracruz. Tropical and Subtropical Agroecosystems 22: 305-314.

Múnera-Bedoya, O.D., L.D. Cassoli, M. Olivera, and M.F. Cerón. 2018. Caracterización de sistemas de producción lechera de Antioquia con sistemas de ordeño mecánico. Livestock Research for Rural Development 30: 5. http://www.lrrd.cipav.org.co//rrd30/5/ceron30086.html.

Nieto, M.l., O. Barrantes, L. Privitello, and R. Reiné. 2018. Greenhouse gas emissions from beef grazing systems in semi-arid rangelands of central Argentina. Sustainability 10: 22.

Orantes-Zebadúa, A., D. Platas-Rosado, V. Córdova-Avalos, M.C. De los Santos-Lara, and A. Córdova-Avalos. 2014. Caracterización de la ganadería de doble proposito en una region de Chiapas, México. Ecosistemas y Recursos Agropecuarios 1: 49-57.

Pagès, J. 2004. Analyse factorielle de donnees mixtes: principe et exemple d'application. Revue de Statistique Appliquée 54: 93-111.

Patiño-Murillo, M., and I. Tobasura-Acuña. 2011. Tomadores de decisión en sistemas ganaderos de la cuenca alta del río Guarinó (Caldas, Colombia): percepción de problemas ambientales y prácticas de conservación del agua. Luna Azuß3: 97-109. 
Puebla-Albiter, S., S. Rebollar-Rebollar, B. Albarrán-Portillo, A. García-Martínez, and C.M. Arriaga-Jordán. 2015. Análisis técnico económico de sistemas de bovinos doble propósito en Tejupilco, Estado de México, en la época de secas. Investigación y Ciencia 23: 13-19.

R Core Team. 2016. R: A language and environment for statistical computing. Vienna: R Foundation for Statistical Computing.

Rangel, J., J.A. Espinosa, C. De Pablos-Heredero, C. Barba, A. Velez, J. Rivas, and A. García. 2017. Adopción de innovaciones y prácticas organizativas de manejo, alimentación y reproducción en pequeñas unidades de producción de vacunos de doble propósito en México. Revista Científica, FCV-LUZ XXVII, 44-55.

Rangel, J., J. Perea, C. De-Pablos-Heredero, J.A. Espinosa-García, P. Toro-Mujica, M. Feijoo, C. Barba, and A. García. 2020. Structural and technological characterization of tropical smallholder farms of dual-purpose cattle in Mexico. Animals 10: 86. https://doi.org/10.3390/ani10010086.

Rivas, L., Holmann, F. 2002. Sistemas de doble propósito y su viabilidad en el contexto de los pequeños y medianos productores en América Latina Tropical. Veracruz: Universidad Nacional Autónoma de México.

Rojo-Rubio, R., J.F. Vázquez-Armijo, P. Pérez-Hernández, G.D. Mendoza-Martínez, A. Z.M. Salem, B. Albarrán-Portillo, A. González-Reyna, et al. 2009. Dual purpose cattle production in Mexico. Tropical Animal Health and Production 41: 715721. https://doi.org/10.1007/s11250-008-9249-8 Springer Netherlands.

Rosero-Noguera, R., and S.L. Posada-Ochoa. 2016. Cálculo de sales minerales para vacunos en pastoreo. Fondo editorial Biogénesis. 1st ed. Medellín: Fondo Editorial Biogénesis.

Ruiz, J.F., M.F. Cerón-Muñoz, R. Barahona-Rosales, and D.M. Bolivar-Vergara. 2019. Caracterización de los sistemas de producción bovina de leche según el nivel de intensificación y su relación con variables económicas y técnicas asociadas a la sustentabilidad. Livestock Research for Rural Development 31.

Ruiz-Guevara, C., L.A. García-Hernández, C.H. Ávila-Bello, and L. Brunett-Pérez. 2008. Sustentabilidad Financiera: El Caso De Una Empresa Ganadera De Bovino De Doble Propósito. Revista Mexicana de Agronegocios XII: 503-515.

Solano, C., A. Bernués, F. Rojas, N. Joaquin, W. Fernandez, and M. Herrero. 2000. Relationships between management intensity and structural and social variables in dairy and dual-purpose systems in Santa Cruz, Bolivia. Agricultural Systems 65: 159-177.

Sotelo, M., J.C. Suárez-Salazar, F. Álvarez-Carrillo, A. Castro-Núñez, V.H. CalderónSoto, and J. Arango. 2017. Sistemas sostenibles de producción ganadera en el contexto amazónico - Sistemas silvopastoriles: ¿una opción viable? 448. Cali: Publicación CIAT.

Urdaneta de Galué, F., M.E. Peña, R. Rincón, J. Romero, and M. Rendón-Ortín. 2008. Gestión y tecnología en sistemas ganaderos de doble propósito (taurus-indicus). Revista Científica 18: 715-724.

Vilaboa-Arroniz, J., and P. Díaz-Rivera. 2009. Caracterización socioeconómica y tecnológica de los sistemas ganaderos en siete municipios del estado de Veracruz, México. Zootecnia Tropical 27: 427-436.

Villate-Calderón, J.A., and C.M. Martínez-Roldán. 2011. Tipificación y diagnóstico de sistemas de producción bovina de ceba, cria y doble propósito, para pequeños y medianos productores de la provincia de Medina, Cundinamarca. Bogotá: Universidad de la Salle.

Yamamoto, Wataru, loan Ap Dewi, and Muhammad Ibrahim. 2007. Effects of silvopastoral areas on milk production at dual-purpose cattle farms at the semi-humid old agricultural frontier in central Nicaragua. Agricultural Systems 94: 368-375. https://doi.org/10.1016/j.agsy.2006.10.011 Elsevier.

\section{Publisher's Note}

Springer Nature remains neutral with regard to jurisdictional claims in published maps and institutional affiliations.

\section{Submit your manuscript to a SpringerOpen ${ }^{\circ}$ journal and benefit from:}

- Convenient online submission

- Rigorous peer review

- Open access: articles freely available online

High visibility within the field

- Retaining the copyright to your article

Submit your next manuscript at $\boldsymbol{\nabla}$ springeropen.com 